\title{
Book Review: Zarzo, E. (2016), Memoria Retórica y Experiencia Estética. Retórica, Estética y Educación. Madrid: Dykinson
}

\author{
Davide Mombelli \\ Department of Spanish studies, University of Alicante, Spain
}

Received: 21-09-2016

doi:10.7575/aiac.ijclts.v.4n.4p.64
Accepted: 25-10-2016

Published: 31-10-2016

\begin{abstract}
Memoria retórica y experiencia estética. Retórica, Estética y Educación, recently published by Dykinson, is a fundamental body of research on rhetoric memory and aesthetic experience, two objects of study which, although having generated much literature separately, have not been considered in their reciprocity until now.

The author, Esther Zarzo, who earned her Ph.D. in Philosophy, has published several investigations of both a theoretical and practical nature concerning the treatment and development of the faculty of memory. From among her theoretical works, standouts include "Historia, memoria y tiempo" (2015a), which addresses the relationship between memory and history from a metaphysical approach in order to explain some of the mnemonic aporiae underlying historical knowledge; and from among her work of a practical nature standouts include, "La mirada topológica" (2013), focused on the media of today's exploitation of the image, and, "The art of memory in the Digital Age" (2015b), in which different implementation strategies of the classical rhetorical techniques found in Virtual Learning Environments are considered. Regarding the investigation's second object, the aesthetic experience, it is important to highlight the author's editing work carried out in collaboration with Prof. Pedro Aullón de Haro of the fundamental work by Alfonso Reyes, El Deslinde (2014), whose concept of literary experience is crucial to understanding the text at hand.
\end{abstract}

As Esther Zarzo explains in the introduction, the choice of such objects of study is justified by the need to analyse the epistemological consequences of the revolution produced by electronic media that enable the external storage and transmission of information, since any modifications to the way of organising and accessing content substantially affects the individual and collective experience, both in regard to knowledge and to self-knowledge, along with the experience of time. According to the author, the problem of memory also brings with it several classic paradoxes, such as those formulated in pairs like the individual / collective, interior / exterior, private / universal. Out of this comes their relevance in human sciences, especially so for history and anthropology, which explains that any alteration in their conception or in their mode of development impacts both individual and collective identity and more generally, social dynamics.

On this basis, as raised by the investigation, if today the connective structure of our culture is being redefined, and, seemingly with a clear tendency to reduce not only memory but also history, it becomes pertinent to analyse how such modifications are taking place, in order to clarify whether the principle that guides it is humanistic or not and, if it is not, propose an alternative relationship that safeguards the experience of the present and of the future.

On the other hand, in terms of experience, as explained in the research, various forms of perception, reception and the communication of knowledge emerge as a result of the media revolution, and, with them, new identities, characterized by fragmentation, whose high media coverage makes them highly manipulable.

Within this theoretical framework, and in Esther Zarzo's opinion, it is indispensable to define a theoretical framework of humanistic character to strengthen such modalities and direct their potential towards the formation of a subject that is focused, and does not lead to the dispersion of subject's attention. This research, therefore, intends to contribute to this humanistic recovery.

Therefore, and here lies the thesis of the work, according to the author's diagnosis, part of the humanistic disintegration observed is centred on two fundamental elements; on the one hand, the experience of the acceleration of external time; and on the other, the lack of considered use of human time or what she calls, "a reduction in intentional time" Thus, she maintains that there is a feedback relationship between the two objects, memory and experience, based on a common element, experience and the considered use of time. The key offered by the art of memory is that, since it participates in both rhetoric and logic, it prevents knowledge from being limited to the rational, demanding an artistic elaboration of the experience, even an aesthetic expression that is not solipsistic but contextualized. So what follows is the proposal of the specification of a concept of modern experience that seeks solidarity with an art of memory as a technique for the internal organization of time that is able to face the humanistically disintegrating effects of this historical process that has been called the Era of Technological Globalization. She does so through a historical reconstruction of the art of memory, from its origin to its modern disintegration, which coincides with the development of the aesthetic experience. According to the author, at the exact time of the changing of historical context, the possibility of defining a type of 
experience that was alternative to the modern one, susceptible to the joint development with the mnemonic art, did in fact exist. The Vico-Crocean tradition, truncated in Europe by war and swept along by the structural-formalism, offered a favourable space for the articulation of a modern and harmonic experience armed with classical techniques. To recover this tradition, the author had to trace the multiple and scattered developments of its fundamental concepts through American and Hispanic thinking, analysing authors like Emerson, Dewey and Santayana.

The first part of the research is an analysis of the historical evolution of the art of memory as techne, from its Greek configuration to what appears to be its contemporary disintegration, which makes clear that it is precisely its historiographical abandonment, as a result of the boom of contemporary formalism, that has favoured its progressive lack of epistemic educational space.

It should be noted that said reconstruction closely follows the text, The Art of Memory by Frances Amelia Yates (1966), however, Esther Zarzo's selection of authors seeks not only to complement the work of Yates by synthesising works of great metaphysical and philosophical depth, such as those by Paolo Rossi (1960), but also to maintain theoretical attention on the substantial change in the conception of memory through the epistemological and metaphysical comparison of the different models, in order to reveal the human dimensions won or lost according to the categorization of the psyche and its social-political impact.

The conclusion of the first part of the research reveals that our present is characterized by an atrophy of the mnemonic spiritual operation which, reinforced by the hypertrophy of imagination and taking on a misunderstood fictionalization capacity, leads to the equalization of the internal intentional time to the external reality, which makes the projecting of future experiences on past experiences impossible. With this ability currently underrated because of the semantic shifts derived from the technological paradigm changes, which equate it to the unteachable mechanical memory, it can be said that the art of memory is almost extinct.

In this situation, the recovery of a notion of man with the ability to consider his faculties, especially memory, sensitivity and desire, as susceptible to development and as fundamental elements to building his internal time, requires the definition of a notion of experience that allows him to experience this potential and responsibility.

Rebuilding a kind of experience that is able to recover this notion of man is the object to which the second part of the research dedicates itself.

Consequently, the second part of the research is a reconstruction of contemporary aesthetic thought with regard to aesthetic experience. The reconstruction of a theoretical concept of experience that is an alternative to the modern experience rooted in the Enlightened period, implies recovering some of the most relevant theoretical elements of the aesthetic innovation that took place in the $20^{\text {th }}$ century, that is, elements developed by American and Hispanic thinking. Kant's work is taken as the starting point for modern experience, in order to reconstruct a concept of experience that is alternative to that from the enlightened period. Then follows the Crocean work, a mature expression of the idealism which offered a concept of experience focused on the process of eidetic definition of the homo poiéticus, complemented by the Aesthetics of Nicolaï Hartmann, focused on the object, the technique of experience and expression.

On this basis, the author undertakes the aforementioned reconstructive operation, following the Pythagorean method, according to which reconstructing a concept of experience that overcomes the modern concept marked by the dualism inherit to tradition, involves selecting a concept of experience able to overcome all of such dualisms.

The Deweyan consummatory experience has been selected to overcome the anthropological dualism between thought and action, the reason in art of Santayana, superseding the epistemological dualism; and a concept capable of solving the split between theory and practice: the philosophy of art defined by Collingwood.

In the process of such reconstruction, one of the concepts adjacent to experience, the concept of expression, reveals itself as fundamental in its definition, to the point that is requires parallel consideration. The author decides to rebuild it following the same procedure. She takes Lezama Lima's concept of aesthetic expression, able to unite spirit and landscape, the epistemological concepts of expression and literary experience defined by Alfonso Reyes, and finally the concept of metaphysical expression developed by Eduardo Nicol.

Again, at the end of this reconstructive proposal, the concept of the experience of time is revealed as a mediator between experience and expression. Its conceptual reconstruction is undertaken again, in order to achieve a concept of anthropological time that is solidary with those already rebuilt, thanks to the complementarity between the concept of time as quehacer (as task) defined by José Ortega y Gasset, the temporeidad of Xavier Zubiri and the tiempo mediador (mediator time) of María Zambrano.

The last duality to be resolved, the relationship between memory and history, both pierced by the experience of time, is solved by addressing the issue from expression in history, and interpreting it as an attribution of temporality, which leads to the analysis of Gadamer and Ricoeur's works.

Thus a current concept of experience is defined, one that assumes the internal and external continuous transitoriness as an element of the reality in which man is integrated, not as a cogitative subject but as an indissoluble part, in which the mnemonic art is perfectly integrated as a spiritual operation of meaning.

After the first two sections, devoted respectively to the historical evolution of the concepts of memory and experience, the third chapter, "Experiencia estética y estética de la experiencia: tiempo y memoria en conclusión" (Aesthetic experience and aesthetics of experience: time and memory, in conclusion), closes with the historical-conceptual reconstruction. The findings raised here lead research into the field of education, since, in Esther Zarzo's view, aesthetic 
education of the memory is the first step toward regaining the experience of intentional time. And as such, the argument that Bildung is put before that of Form, is recovered here. A Bildung in which what is fundamental is not the resulting product, but the interior forming process in constant development. The realization that is explored is precisely its compound element of Bild, of image; that image that is imitated and in turn, also modelled to imitate, build and developed by oneself. The matter is exercising the ability to see the image as a harmonious development of different elements, that includes in it the past, present and future, all of which would contribute to the normalization of the synthetic experience, and with it, of the perception of the relational nature of reality that man inhabits.

With these criteria, the author believes that the most fruitful point of intervention is located in the processing of the image, as today this is a form of collective cognition. It is therefore necessary to emancipate the image from its media exploitation and restore its educational value. To do this, the author designs a series of teaching strategies to implement the art of memory in Virtual Learning Environments, in order to provide knowledge with imaginal organization. In doing so she seeks to contribute to the pressing concerns of the educational community to provide a humanistic orientation to what is called cyberspace.

It is the pedagogical aspect of the study that translates into practice, as outlined in the premises, the theoretical framework. And in our view, the most relevant part to current education, and to which, perhaps, more space should have been devoted, is in delving further into an analysis of the methodology that is to be employed. However, the explanations contained there are enough to understand the scope and profitability of the innovative proposals, that combining tradition and new information technology are indicated by the author.

In conclusion, in her book, Esther Zarzo performs three basic operations: the reconstruction of the concept and historical development of the mnemonic art; the reconstruction of a theoretical concept of experience that is alternative to the modern experience, with roots of the Enlightenment, solidary with the art of memory; and the projection and proposal for a recovery of today's aesthetic experience of memory and time.

It is, in short, a book of indispensable reading, because the mere fact of being aware of the underlying fallacies of the current treatment of memory and imagination leads to a very significant change in attitude towards reality and to the recovery of a practical sense of truth that unifies the human experience in the exercise of freedom and dignity.

In the words of Esther Zarzo, its purpose, at a time like the present, characterized by the poverty of experience, as has been previously qualified by Walter Benjamin, is to recover experience understood with the "auténtico significado de la raíz per, es decir, penetrante, profundizadora, y capaz de percibir lo que aparece en la mera sensación” (p. 306), (true meaning of the root per, i.e., penetrating, delving and able to perceive what appears to be just mere sensation). Overcoming solipsism and not only assuming inter-subjectivity as defining identity but also the historicity founded in a hermeneutical and narrative memory which also includes the dimension of participation as expression. Education always paves the way for intervention.

As a last point, we note that the next book by the author devoted to this subject, El arte clásico de la memoria (The classical art of memory) has already been announced, and interested students can find the art of memory texts anthologised in a bilingual edition.

\section{References}

Aullón de Haro, P. \& E. Zarzo (eds.) (2014). El Deslinde. Prolegómenos a la Teoría Literaria. Madrid: Verbum.

Rossi, P. (1960). Clavis Universalis. Arti Mnemoniche e logica combinatoria da Lullo a Leibniz. Milano-Napoli: Riccardo Ricciardi.

Yates, F. A. (1966). The Art of Memory. United Kingdom: Routledge and Kegan Paul.

Zarzo, E. (2013). Una mirada topológica. Argumentación 'perceptiva'. Revista de Filosofia Eikasía, VI, 49, 79-96. ISSN $1885-5679$.

Zarzo, E. (2015a). Historia, memoria y tiempo. Historiografía y Teoría de la Historia del pensamiento, la literatura y el arte. Madrid: Dykinson. 107-128. ISBN: 978-84-9085-439-6.

Zarzo, E. (2015b). The art of memory in the Digital Age. Procedia. Social and Behavioral Sciences, 178, $222-226$. ISSN: 1877- 0428. 